\title{
ANALISIS KAUSALITAS ANTARA PERTUMBUHAN EKONOMI, SEKTOR PARIWISATA, KETIMPANGAN DISTRIBUSI PENDAPATAN DAN KEMISKINAN DI KABUPATEN BADUNG
}

\author{
I Komang Wiradnyana ${ }^{1}$ I K. G. Bendesa ${ }^{2}$
}

Article history:

Submitted: 5 Maret 2021

Revised: 20 Maret 2021

Accepted: 14 Mei 2021

\section{Keywords:}

Economic growth;

Tourism Sector;

Inequality of Income

Distribution;

Poverty;

\section{Kata Kunci:}

Pertumbuhan Ekonomi;

Sektor Pariwisata;

Ketimpangan

Distribusi

Pendapatan;

Kemiskinan;

\section{Koresponding:}

Fakulas Ekonomi dan Bisnis

Universitas Udayana, Bali,

Indonesia

Email:

Wiradnyanakomang44@gmail. com
Abstract

Economic growth, the tourism sector, inequality in income distribution and poverty are economic variables used to see the success of a region's development. The purpose of this study was to determine the relationship between the independent variables, namely economic growth, the tourism sector, inequality in income distribution, and the dependent variable on poverty in Badung Regency. This study uses secondary data with multiple linear regression analysis techniques, and previously conducted the Granger causality test to see the causal relationship between variables. The results showed that simultaneously economic growth, the tourism sector and inequality had a significant effect on poverty. Partially only the tourism sector that affects poverty. The results of the Granger causality analysis show that there is a one-way relationship between the tourism sector and poverty, there is no causality relationship between poverty and economic growth and there is no causality relationship between income inequality and poverty.

\begin{tabular}{l} 
Abstrak \\
\hline Pertumbuhan ekonomi, sektor pariwisata, ketimpangan distribusi \\
pendapatan dan kemiskinan merupakan variabel ekonomi yang digunakan \\
untuk melihat keberhasilan pembangunan suatu wilayah. Tujuan penelitian \\
ini adalah untuk mengetahui hubungan variabel independent yaitu \\
pertumbuhan ekonomi, sektor pariwisata, ketimpangan distribusi \\
pendapatan, dan variabel dependen kemiskinan di Kabupaten Badung. \\
Penelitian ini menggunakan data skunder dengan teknik analisis regresi \\
linear berganda, dan sebelumnya dilakukan uji kausalitas Granger untuk \\
melihat hubungan sebab akibat antar variabel. Hasil penelitian menunjukkan \\
bahwa secara simultan pertumbuhan ekonomi, sektor pariwisata dan \\
ketimpangan berpengaruh signifikan terhadap kemiskinan. Secara parsial \\
hanya sektor pariwisata yang memengaruhi kemiskinan. Hasil analisis \\
kausalitas Granger menunjukan terdapat hubungan satu arah antara sektor \\
pariwisata dengan kemiskinan, tidak terdapat hubungan kausalitas antara \\
kemiskinan dengan pertumbuhan ekonomi dan tidak terdapat hubungan \\
kausalitas antara ketimpangan pendapatan terhadap kemiskinan.
\end{tabular}

Fakultas Ekonomi dan Bisnis Universitas Udayana, Bali, Indonesia ${ }^{2}$

Email: ikgbendesa@unud.ac.id 


\section{PENDAHULUAN}

Tingkat pertumbuhan ekonomi menunjukkan peningkatan kinerja suatu perekonomian. Namun, apabila pertumbuhan ekonomi yang tinggi tidak selaras dengan pemerataam pembangunan di semua golongan masyarakat maka ketimpangan pendapatan akan tetap terjadi (Todaro, 2011). Pertumbuhan ekonomi dapat dilihat melalui peningkatan pertumbuhan ekonomi yang sejalan dengan penurunan penduduk miskin pada suatu daerah (Sasana dan Kusuma, 2018). Pertumbuhan ekonomi dapat diamati dari pertumbuhan nilai Produk Domestik Regional Bruto (PDRB). Salah satu sektor yang memberikan sumbangan besar dalam Pendapatan Asli Daerah (PAD) adalah sektor pariwisata. Dari sudut pandang ekonomi makro, pariwisata berdampak positif terhadap peningkatan pendapatan daerah, dan juga memberikan peluang kerja terutaa bagi masyarakat di sekitar tempat wisata (Ismalisa dan Anis, 2019).

Dinny (2020) berpendapat bahwa sektor pariwisata adalah penyumbang pendapatan terbesar bagi pertumbuhan ekonomi Provinsi Bali. Pembangunan pariwisata Bali memberikan dampak yang cukup signifikan terhadap pertumbuhan ekonomi Bali. Berdasarkan informasi dari BPS (2020) pertumbuhan ekonomi Bali pada tahun 2018 mencapai angka 6,33 persen dimana angka tersebut menunjukkan bahwa pertumbuhan mengalami penurunan pada tahun 2019 yang mencapai 5,63 persen. Dilihat dari sisi permintaan, perlambatan pertumbuhan ekonomi terjadi karena kinerja ekspor luar negeri dan invetasi yang menurun. Dari sisi penawaran, terlihat dari tertahannya kinerja lapangan usaha pertanian, lapangan usaha konstruksi, lapangan usaha perdagangan, dan lapangan usaha penyediaan akomodasi makan-minum. Sementara pertumbuhan ekonomi yang tinggi pada tahun 2018 terjadi karena adanya base effect penyelenggaraan Annual Meeting 2018, musim kemarau yang berlangsung lebih lama, dan perlambatan ekonomi mitra dagang utama Bali (Trisno, 2020).

Perkembangan pariwisata di Bali khususnya Kabupaten Badung memicu terjadinya ketimpangan pendapatan antar wilayah. Damanik (dalam Adhitya Bagus, 2020) menyebutkan bahwa ketimpangan dapat terjadi karena perbedaan jumlah penduduk, sumber daya alam, dan pembangunan yang tidak merata. Ketimpangan terjadi karena adanya perbedaan pendapatan masyarakat di daerah maju dengan daerah tertinggal. Masyarakat dengan pendapatan lebih tinggi mempunyai daya beli lebih besar dari masyarakat dengan pendapatan rendah, sehingga pada jangka panjang akan menimbulkan gap antar masyarakat (Rifki, 2019). Berdasarkan data gini rasio kabupaten/kota dan Provinsi Bali tahun 2014 - 2019 diketahui bahwa pada tahun 2019 Kabupaten Klungkung menduduki peringkat pertama mencapai 0,39, sedangkan Provinsi Bali menduduki peringkat kedua mencapai 0,38 dan diikuti oleh empat kabuaten/kota yang mencapai angka masing-masing 0,34. Terlihat bahwa ketimpangan pendapatan di kabupaten/kota dan Bali cenderung mengalami peningkatan. Hal ini mengindikasikan bahwa program pemerintah belum mampu menurunkan ketimpangan, dan sektor pariwisata di Bali juga belum mampu mengatasi masalah tersebut. Meskipun Kabupaten Badung memiliki pendapatan yang besar, ternyata tidak menjamin terjadinya pemerataan distribusi pendapatan. Hal tersebut tidak sejalan dengan penelitian Samimi dkk. (2011) yang menjelaskan bahwa sektor pariwisata dapat meratakan pembangunan dari pusat ekonomi ke daerah tertinggal.

Analisis Kausalitas Antara Pertumbuhan Ekonomi, Sektor Pariwisata, Ketimpangan Distribusi Pendapatan dan Kemiskinan di Kabupaten Badung, I Komang Wiradnyana dan I.K.G.Bendesa 
Tabel 1.

Gini Rasio Provinsi Bali Menurut Kabupaten/Kota Tahun 2014-2019

\begin{tabular}{clcccccc}
\hline No & Kabupaten/Kota & $\mathbf{2 0 1 4}$ & $\mathbf{2 0 1 5}$ & $\mathbf{2 0 1 6}$ & $\mathbf{2 0 1 7}$ & $\mathbf{2 0 1 8}$ & $\mathbf{2 0 1 9}$ \\
\hline 1. & Jembrana & 0.37 & 0.39 & 0.31 & 0.36 & 0.32 & 0.33 \\
2. & Tabanan & 0.39 & 0.4 & 0.36 & 0.34 & 0.31 & 0.32 \\
3. & Badung & 0.35 & 0.34 & 0.31 & 0.32 & 0.32 & 0.34 \\
4. & Gianyar & 0.33 & 0.38 & 0.32 & 0.3 & 0.27 & 0.31 \\
5. & Klungkung & 0.36 & 0.35 & 0.37 & 0.36 & 0.37 & 0.39 \\
6. & Bangli & 0.31 & 0.33 & 0.38 & 0.35 & 0.3 & 0.31 \\
7. & Karangasem & 0.33 & 0.34 & 0.31 & 0.29 & 0.32 & 0.34 \\
8. & Buleleng & 0.38 & 0.39 & 0.34 & 0.34 & 0.31 & 0.34 \\
9. & Denpasar & 0.36 & 0.38 & 0.36 & 0.33 & 0.34 & 0.34 \\
\hline & Provinsi Bali & $\mathbf{0 . 4}$ & $\mathbf{0 . 4 2}$ & $\mathbf{0 . 3 8}$ & $\mathbf{0 . 3 7}$ & $\mathbf{0 . 3 8}$ & $\mathbf{0 . 3 8}$ \\
\hline
\end{tabular}

Sumber: BPS Provinsi Bali, 2020

Kabupaten Badung memiliki 30 (tiga puluh) desa/kelurahan yang penduduknya sebagian besar bekerja pada sektor pertanian. Semua desa/kelurahan tersebut berada di tiga kecamatan Badung bagian Utara yaitu, Kecamatan Mengwi terdapat 9 desa, Kecamatan Abiansemal terdapat 14 dan Kecamatan Petang terdapat 7 desa. Hal tersebut mengindikasikan bahwa pembagunan pariwisata yang ada di Kabupaten Badung masih berpusat pada daerah bagian selatan.

Sirilius (2017) mengemukakan bahwa kemiskinan merupakan keadaan yang serba kekurangan dialami oleh sekelompok orang, sehingga mereka tidak mampu untuk menikmati kesehatan yang layak, pendidikan yang tinggi, dan konsumsi makanan yang kurang layak dari segi kesehatan. Meskipun pemerintah telah melaksanakan berbagai program pengentasan kemiskinan, namun nyatanya belum sepenuhnya dapat mengentaskan kemiskinan (Dariwardani, 2014). Menurut data enam tahun terakhir, Kabupaten Badung memiliki PAD tertinggi dari tahun 2014-2019 dibandingkan kabupaten/kota yang ada di Provinsi Bali. Tingginya PAD dapat membantu menjalankan program untuk masyarakat Badung serta di luar daerah Badung, dengan tujuan meringankan bedan masyarakat dalam melestarikan dan menjaga adat, tradisi, seni dan budaya Bali (Pemkab Badung, 2019). Dalam kurun waktu sepuluh tahun terakhir, persentase penduduk miskin di Kabupaten Badung mengalami penurunan. Namun sampai saat ini belum ada kebijakan yang mampu mengurangi penduduk miskin secara signifikan yang ditemukan oleh Kabupaten Badung. Pengkajian konsep kemiskinan, mengukur keberhasilan pengentasan kemiskinan, dan strategi penanganan kemiskinan masih terus diupayakan agar kemiskinan tidak lagi menjadi masalah dalam kehidupan manusia (Windia, 2015).

Sovia (2018) mengemukakan bahwa adanya hubungan jangka panjang antara tingkat kemiskinan dan pertumbuhan ekonomi. Nova (2019) menjelaskan bahwa pertumbuhan ekonomi dapat mengurangi kemiskinan jika padat karya, sedangkan jika pada modal maka akan meningkatkan pengangguran yang kemudian kemiskinan juga meningkat. Penelitian yang dilakukan oleh Pradeep (2018) menemukan bahwa daerah dengan tingkat pertumbuhan yang lebih tinggi akan mencapai tingkat penurunan angka kemiskinan yang lebih cepat. Konsep pertumbuhan pro-poor dapat menjadi konsep penting untuk meningkatkan pertumbuhan ekonomi, mengatasi kemiskinan dan ketimpangan suatu wilayah (Risqi dkk., 2019). Dalam studi yang dilakukan oleh Suhel dan Abdul Bashir (2018) menemukan bahwa ada hubungan satu arah antara sektor pariwisata dan pertumbuhan ekonomi, 
sementara investasi di bidang pariwisata memiliki hubungan dua arah dengan pertumbuhan ekonomi di Sumatera Barat.

\section{METODE PENELITIAN}

Desain penelitian ini merupakan penelitian asosiatif yang bersifat kausal. Penelitian dilakukan di Kabupaten Badung, karena merupakan daerah dengan pendapatan dari sektor pariwisata paling besar di Provinsi Bali namun masih belum dapat terbebas dari masalah ketimpangan pendapatan antar wilayah dan kemiskinan dan juga mengalami pertumbuhan ekonomi yang cenderung menurun dalam kurun waktu lima tahun terakhir. Adapun objek dari penelitian adalah pertumbuhan ekonomi, sektor pariwisata, ketimpangan pendapatan dan kemiskinan. Jenis data yang digunakan yaitu data kuantitatif mengenai tingkat pertumbuhan ekonomi, sumbangan sektor pariwisata terhadap PDRB, rasio gini dan jumlah penduduk miskin di Kabupaten Badung selama dua puluh lima tahun terakhir, dan data kualitatif terutama teori-teori mengenai pertumbuhan ekonomi, sektor pariwisata, ketimpangan pendapatan dan kemiskinan.

Sumber data diperoleh dari Badan Pusat Statistik (BPS) Provinsi Bali dan Badan Pusat Statistik (BPS) Kabupaten Badung. Metode pengumpulan datang yang digunakan yaitu metode observasi non partisipan yang dilakukan dengan cara mengamati, mencatat, serta mempelajari uraian dari buku-buku, artikel, ilmiah berupa jurnal, skripsi, dan dokumen-dokumen yang terdapat dari instansi terkait seperti BPS Provinsi Bali, BPS Kabupaten Badung dan buku-buku literatur tentang pertumbuhan ekonomi, sektor pariwisata, ketimpangan distribusi pendapatan dan kemiskinan. Teknik analisis yang digunakan dalam penelitian ini adalah analisis data deskriptif untuk memberikan gambaran mengenai suatu data agar data yang tersaji lebih mudah dipahami dan informatif, dan analisis regresi linier berganda untuk menunjukkan arah hubungan antara variabel dependent (variabel terikat) dengan variabel independent (variabel bebas). Penelitian ini menggunakan metode Granger causality test dengan menggunakan Software Eviews 9 yang digunakan untuk mengklarifikasi adanya arah dari kausalitas antara variabel-variabel tersebut (Ulke, 2011).

\section{HASIL DAN PEMBAHASAN}

Pertumbuhan ekonomi dapat diartikan sebagai perkembangan suatu perekonomian atau kenaikan jangka panjang dalam kemampuan suatu negara untuk memproduksi barang dan jasa secara berkesinambungan yang dapat diukur dengan pertumbuhan Produk Domestik Regional Bruto. Berdasarkan data Pertumbuhan Ekonomi Atas Dasar Harga Konstan Kabupaten Badung pada Tahun 1995 - 2019 (BPS, 2020), diketahui bahwa kondisi pertumbuhan ekonomi di Kabupaten Badung dalam kurun waktu dua puluh lima tahun terakhir mengalami fluktuasi. Pertumbuhan ekonomi tertinggi yang pernah dicapai oleh Kabupaten Badung terjadi pada Tahun 1996 yakni mencapai 9,09 persen. Pertumbuhan ekonomi yang tinggi pada tahun ini disebabkan karena pesatnya pembangunan pariwisata. Sedangkan Kabupaten Badung mencapai pertumbuhan ekonomi terendah pada Tahun 1998 yakni mencapai $-4,96$ persen. Rendahnya pertumbuhan ekonomi pada tahun 1998 dipicu karena terjadinya krisis moneter global yang berdampak langsung terhadap melemahnya perekonomian. Jika kita melihat kondisi pertumbuhan ekonomi dalam kurun waktu lima tahun terakhir, pertumbuhan cenderung mengarah kepada penurunan. Tercatat pertumbuhan ekonomi pada tahun 2014 pernah 
mencapai 6,98 persen, namun tingginya pertumbuhan tersebut tidak dijaga pada tahun-tahun berikutnya sehingga pertumbuhan ekonomi pada Tahun 2019 tercatat hanya 5,83 persen, menurun jika dibandingkan dengan tahun sebelumnya.

Sektor pariwisata merupakan sektor yang mampu meningkatkan pendapatan daerah guna meningkatkan pertumbuhan ekonomi. Kontribusi sektor pariwisata terhadap perekonomian suatu wilayah dapat dilihat dari sumbangan akomodasi dan makan minum terhadap PDRB. Dalam kurun waktu dua puluh lima tahun terakhir, sektor pariwisata memberikan kontribusi terhadap PDRB Kabupaten Badung namun cenderung mengalami penurunan. Penurunan terjadi karena adanya perkembangan di sektor-sektor ekonomi lainnya seperti sektor perdagangan dan pertanian. Jadi sektor pariwisata secara tidak langsung mendorong perkembangan sektor-sektor lainnya terutama sektor pendukung pariwisata.

Ketimpangan pendapatan adalah suatu kondisi dimana distribusi pendapatan yang diterima masyarakat tidak merata yang dapat dilihat melalui gini rasio. Perkembangan gini rasio di Kabupaten Badung selama dua puluh lima tahun terakhir cenderung fluktuasi. Menurut data yang dikeluarkan oleh BPS, Kabupaten Badung mencapai pemerataan distribusi pendapatan yang terbaik pada Tahun 2007 yakni sebesar 0,17 poin. Setelah Tahun 2007 justru kondisi mengarah kepada ketimpangan yang semakin meningkat dari tahun ke tahun. Bahkan, pada tahun 2019 mencapai 0,35 poin yang menggambarkan ketimpangan distribusi pendapatan semakin tinggi bahkan mengarah pada ketimpangan seperti pada Tahun 1995 mencapai 0,37 poin. Semakin pesatnya perkembangan pariwisata di Kabupaten Badung sudah memberi pengaruh yang besar terhadap besarnya Pendapatan Asli Daerah (PAD) sehingga memberikan keleluasaan kepada pemerintah untuk membuat berbagai kebijakan yang mengarah kepada pemerataan. Namun jika dilihat dari data yang ada, kebijakan yang dibuat belum mampu sepenuhnya memberikan pemerataan distribusi pendapatan kepada masyarakat.

Kemiskinan adalah keadaan individu atau sekelompok orang yang tidak mampu memenuhi kebutuhan dasarnya yang dapat dilihat dari jumlah penduduk yang belum mampu untuk memenuhi kebutuhan pokok (dikategorikan miskin). Menurut data dari BPS (2020), jumlah penduduk miskin Kabupaten Badung dalam kurun dua puluh lima tahun terakhir cenderung mengalami penurunan. Tercatat pada Tahun 2000 jumlah penduduk miskin tertinggi Kabupaten Badung yakni mencapai 23,21 ribu jiwa. Setelah tahun 2000 jumlah penduduk miskin terus mengalami penurunan hingga tahun 2019 mencapai angka kemiskinan yang paling rendah yakni sebesar 11,89 ribu jiwa. Hal tersebut dapat terjadi tidak terlepas dari pesatnya sektor pariwisata yang berada di Kabupaten Badung. Pesatnya pekembangan sektor pariwisata menyebabkan meningkatnya pendapatan masyarakat Kabupaten Badung sehingga kebutuhan pokok dapat terpenuhi dengan baik.

Berdasarkan hasil analisis diketahui bahwa jumlah pengamatan pada penelitian ini yaitu 25 data dengan rentang waktu selama tahun 1995 - 2019. Variable Kemiskinan memiliki nilai tertinggi sebesar 23.21 ribu jiwa yang terjadi pada tahun 2000, dan terendah sebesar 11.89 ribu jiwa pada tahun 2019. Nilai mean dan median sebesar 17.6588 ribu jiwa dan 17.7 ribu jiwa, dengan nilai standar deviasi sebesar 3.932927 ribu jiwa. Nilai mean lebih besar dari standar deviasi, sehingga dapat disimpulkan bahwa rata-rata dari seluruh data pada variabel kemiskinan mampu menggambarkan seluruh variabel dengan baik. Jika dibandingkan dengan kabupaten/kota di Provinsi Bali, Kabupaten Badung dikategorikan sebagai daerah dengan angka kemiskinan yang rendah. Variabel Ketimpangan Distribusi Pendapatan memiliki nilai tertinggi sebesar 0.37 poin pada tahun 1995, dan terendah sebesar 0.17 poin pada tahun 2007. Nilai mean dan median sebesar 0.2916 poin dan 0.31 poin, dengan nilai standar deviasi sebesar 0.053047 poin. Nilai mean lebih besar dari standar deviasi, sehingga

Analisis Kausalitas Antara Pertumbuhan Ekonomi, Sektor Pariwisata, Ketimpangan Distribusi Pendapatan dan Kemiskinan di Kabupaten Badung, I Komang Wiradnyana dan I.K.G.Bendesa 
dapat disimpulkan bahwa rata-rata dari seluruh data pada variabel ketimpangan distribusi pendapatan mampu menggambarkan seluruh variabel dengan baik.

Tabel 2.

Hasil Analisis Statistik Deskriptif

\begin{tabular}{lrrrr}
\hline & \multicolumn{1}{c}{ K } & \multicolumn{1}{c}{ KDP } & \multicolumn{1}{c}{ PE } & \multicolumn{2}{c}{ SP } \\
\hline Mean & 17.6588 & 0.2916 & 5.5288 & 39.3532 \\
Median & 17.7 & 0.31 & 6.39 & 38.95 \\
Maximum & 23.21 & 0.37 & 9.09 & 46.11 \\
Minimum & 11.89 & 0.17 & -4.96 & 34.26 \\
Std. Dev. & 3.932927 & 0.053047 & 2.873921 & 4.121873 \\
Observations & 25 & 25 & 25 & 25 \\
\hline
\end{tabular}

Keterangan: $\mathrm{K}=$ Kemiskinan (Ribuan Jiwa); KDP = Ketimpangan Distribusi (Poin) Pendapatan; PE = Pertumbuhan Ekonomi (\%); SP= Sektor Pariwisata (\%) Sumber: Data diolah dengan eviews 9, 2020

Variabel Pertumbuhan Ekonomi memiliki nilai tertinggi sebesar 9.09 persen pada tahun 1996, dan terendah sebesar -4.96 persen pada tahun 1998. Nilai mean dan median sebesar 5.5288 persen dan 6.39 persen, dengan nilai standar deviasi sebesar 2.873921. Nilai mean lebih besar dari standar deviasi, sehingga dapat disimpulkan bahwa rata-rata dari seluruh data pada variabel pertumbuhan ekonomi mampu menggambarkan seluruh variabel dengan baik. Variabel Sektor Pariwisata memiliki nilai tertinggi sebesar 46.11 persen pada tahum 1998, dan terendah sebesar 34.26 persen pada tahun 2012. Nilai mean dan median sebesar 39.3532 persen dan 38.95 persen, dengan nilai standar deviasi sebesar 4.121873. Nilai mean variabel lebih besar dari standar deviasi, sehingga dapat disimpulkan bahwa rata-rata dari seluruh data pada variabel sektor pariwisata mampu menggambarkan seluruh variabel dengan baik.

Tabel 3.

Hasil uji Stasioneritas Menggunakan Metode Augmented Dickey-Fuller (ADF)

\begin{tabular}{ccccc}
\hline Variabel & ADF & $\begin{array}{c}\text { Mc Kinnon Critical } \\
\text { Value 5\% }\end{array}$ & P-Value & Keterangan \\
\hline PE & -3.07778 & -3.020686 & 0.0447 & $\begin{array}{c}\text { Stasioner pada ordo level } \\
\text { SP }\end{array}$ \\
KDP & -5.99019 & -2.998064 & 0.0001 & Stasioner pada ordo 1 \\
K & -5.69203 & -2.998064 & 0.0001 & Stasioner pada ordo 1 \\
\hline
\end{tabular}

Keterangan: $\mathrm{K}=$ Kemiskinan; KDP = Ketimpangan Distribusi Pendapatan; PE = Pertumbuhan Ekonomi; SP= Sektor Pariwisata

Sumber: Data diolah dengan eviews 9, 2020

Analisis Kausalitas Antara Pertumbuhan Ekonomi, Sektor Pariwisata, Ketimpangan Distribusi Pendapatan dan Kemiskinan di Kabupaten Badung, I Komang Wiradnyana dan I.K.G.Bendesa 
Berdasarkan hasil uji stasioneritas diatas, semua variabel telah memenuhi persyaratan data uji ADF, bilamana nilai ADF t-statistik telah lebih kecil daripada nilai Mc Kinnon Critical Value 5 persen pada tingkat level (0) dan first difference. Selain itu, nilai $p$-value atau probabilitas dari semua variabel sudah lebih kecil dari $a=0,05$. Dengan demikian, semua variabel data telah stasioner, maka dapat dilakukan langkah selanjutnya dalam estimasi VECM, yakni penentuan panjang lag optimal.

Penentuan lag optimum bertujuan untuk mengetahui lamanya periode keterpengaruhan suatu variabel terhadap variabel masa lalunya maupun terhadap variabel endogen lainnya.

Tabel 4.

Hasil Analisis Uji Lag Optimal

\begin{tabular}{cccccc}
\hline Lag & LR & FPE & AIC & SC & HQ \\
\hline 1 & 21.58282 & 0.016762 & 7.225571 & 8.220354 & 7.441465 \\
2 & $27.24714^{*}$ & 0.009695 & 6.478785 & 8.269395 & 6.867393 \\
$\mathbf{3}$ & $\mathbf{2 0 . 5 2 1 3 4}$ & $\mathbf{0 . 0 0 6 2 2 7 *}$ & $\mathbf{5 . 4 3 7 4 2 7 ^ { * }}$ & $\mathbf{8 . 0 2 3 8 6 4}$ & $\mathbf{5 . 9 9 8 7 5 0 *}$ \\
\hline
\end{tabular}

Sumber: Data diolah dengan eviews 9, 2020

Berdasarkan hasil pengujian diketahui bahwa panjang lag optimal terletak pada lag 3. Penentuan tersebut ditentukan dengan melihat nilai Akaike Information Critterion (AIC) yang paling rendah. Nilai yang ditunjukkan oleh lag 3 merupakan nilai terkecil dari Akaike Information Critterion (AIC) yaitu sebesar 5.437427 jika dibandingkan dengan nilai lag 1 dan lag 2. Dengan demikian, lag optimal yang digunakan dalam penelitian ini adalah lag 3 .

Tabel 5.

Hasil Analisis Uji Kointegrasi Menggunakan Metode Johansen

\begin{tabular}{|c|c|c|c|c|}
\hline $\begin{array}{c}\text { Hypothesized No. of } \\
\text { CE(s) }\end{array}$ & Eigenvalue & Trace Statistic & 0.05 Critical Value & Prob.** \\
\hline None * & 0.999905 & 259.2681 & 47.85613 & 0.0001 \\
\hline At most $1 *$ & 0.870932 & 64.67306 & 29.79707 & 0.0000 \\
\hline At most $2 *$ & 0.573134 & 21.67735 & 15.49471 & 0.0051 \\
\hline At most 3 & 0.165539 & 3.800354 & 3.841466 & 0.0512 \\
\hline $\begin{array}{c}\text { Hypothesized No. of } \\
\text { CE(s) }\end{array}$ & Eigenvalue & Max-Eigen Statistic & 0.05 Critical Value & Prob.** \\
\hline None * & 0.999905 & 194.5950 & 27.58434 & 0.0001 \\
\hline At most $1 *$ & 0.870932 & 42.99570 & 21.13162 & 0.0000 \\
\hline At most $2 *$ & 0.573134 & 17.87700 & 14.26460 & 0.0129 \\
\hline At most 3 & 0.165539 & 3.800354 & 3.841466 & 0.0512 \\
\hline
\end{tabular}

Sumber: Data diolah dengan eviews 9, 2020

Analisis Kausalitas Antara Pertumbuhan Ekonomi, Sektor Pariwisata, Ketimpangan Distribusi Pendapatan dan Kemiskinan di Kabupaten Badung, I Komang Wiradnyana dan I.K.G.Bendesa 
Dari hasil pengujian diketahui bahwa adanya tiga kointegrasi yang dilihat dari nilai trace statistic lebih besar dari critical value 0,05 atau nilai prob lebih kecih dari pada 5 persen maka dapat diindikasikan bahwa terdapat hubungan jangka panjang antar variabel. Selain itu nilai dari max-eigen statistic lebih besar dari nilai critical value 0,05 atau nilai prob lebih kecil dari pada 5 persen. Berdasarkan hasil tersebut maka dapat diartikan bahwa terdapat hubungan jangka panjang antara pertumbuhan ekonomi, sektor pariwisata, ketimpangan distribusi pendapatan dan kemiskinan di Kabupaten Badung.

Tabel 6.

Hasil Pengujian Kointegrasi Multivariat

\begin{tabular}{cccc}
\hline $\mathbf{K}$ & $\mathbf{K D P}$ & $\mathbf{P E}$ & $\mathbf{S P}$ \\
\hline 1.000000 & 0.000000 & -0.105371 & -1.400868 \\
& & $(0.15085)$ & $(0.06828)$ \\
0.000000 & 1.000000 & 0.043263 & 0.026356 \\
& & $(0.00069)$ & $(0.00031)$ \\
\hline
\end{tabular}

Keterangan: K = Kemiskinan; KDP = Ketimpangan Distribusi Pendapatan; PE = Pertumbuhan Ekonomi; $\mathrm{SP}=$ Sektor Pariwisata

Sumber: Data diolah dengan eviews 9, 2020

Hasil pengujian menunjukkan hubungan jangka panjang antara variabel petumbuhan ekonomi, sektor pariwisata terhadap ketimpangan distribusi pendapatan dan kemiskinan di Kabupaten Badung. Diketahui dalam jangka panjang peningkatan pertumbuhan ekonomi sebesar 1 persen akan menyebabkan penurunan terhadap kemiskinan sebesar 0,10 persen dan ketimpangan pendapatan sebesar 0,04 persen. Hasil ini searah dengan penelitian yang dilakukan oleh Stephanie (2017) menemukan bahwa dalam jangka panjang pertumbuhan ekonomi berkontribusi pada penurunan kemiskinan dan ketimpangan. Pertumbuhan ekonomi dalam jangka panjang berarti peningkatan kapasitas perekonomian dalam hal modal fisik, teknologi dan modal manusia (Mahaendra dkk., 2018). Peningkatan kontribusi sektor pariwisata sebesar 1 persen akan menyebabkan penurunan terhadap jumlah penduduk miskin sebesar 1,40 persen. Selaras dengan penelitian yang dilakukan oleh Dody dan Yunanto (2016) yang menemukan bahwa sektor pariwisata berpengaruh signifikan terhadap penurunan kemiskinan. Disamping memiliki memiliki hubungan yang negatif terhadap kemiskinan, sektor pariwisata juga mempunyai hubungan yang positif dengan ketimpangan pendapatan. Berdasarkan hasil uji, peningkatan kontribusi sektor pariwisata dalam jangka panjang akan menyebabkan peningkatan ketimpangan pendapatan sebesar 0,02 persen. Pesatnya perkembangan pariwisata secara tidak merata menyebabkan penyerapan tenaga kerja hanya berasal dari daerah sekitar saja, sehingga pemerintah diharapkan dapat memberikan kebijakan seperti pengembangan pusat-pusat ekonomi sesuai dengan potensi daerah.

Uji kausalitas Granger merupakan metode analisis yang digunakan untuk mengetahui hubungan dimana hubungan antar variabel dependen dapat dipengaruhi oleh variabel lain dan variabel

Analisis Kausalitas Antara Pertumbuhan Ekonomi, Sektor Pariwisata, Ketimpangan Distribusi Pendapatan dan Kemiskinan di Kabupaten Badung, I Komang Wiradnyana dan I.K.G.Bendesa 
independen dapat menjadi variabel dependen (Gujarati, 2003). Jika probabilitas lebih kecil dari $\alpha=$ 0.05 , berarti suatu variabel akan mempengaruhi variabel lain.

Tabel 7.

Hasil Analisis Uji kausalitas Granger

\begin{tabular}{lccc}
\hline Null Hypothesis: & Obs & F-Statistic & Prob. \\
\hline & & & \\
PE does not Granger Cause SP & 23 & 0.63152 & 0.5432 \\
SP does not Granger Cause PE & & 4.57168 & 0.0248 \\
& 23 & 2.53870 & 0.1068 \\
KDP does not Granger Cause SP & & 3.09158 & 0.0701 \\
SP does not Granger Cause KDP & 23 & 0.33309 & \\
& & 4.1046 & 0.7210 \\
K does not Granger Cause SP & 23 & 0.67313 & 0.0340 \\
SP does not Granger Cause K & & 4.56883 & 0.5225 \\
& & & 0.0248 \\
KDP does not Granger Cause PE & 23 & 2.22106 & 0.1374 \\
PE does not Granger Cause KDP & & 1.34913 & 0.2845 \\
& & & \\
K does not Granger Cause PE & 23 & 5.33277 & 0.0152 \\
PE does not Granger Cause K & & 0.47847 & 0.6274 \\
\hline
\end{tabular}

Keterangan: $\mathrm{K}=$ Kemiskinan; KDP = Ketimpangan Distribusi Pendapatan; $\mathrm{PE}=$ Pertumbuhan Ekonomi; $\mathrm{SP}=$ Sektor Pariwisata

Sumber: Data diolah dengan eviews 9, 2020

Berdasarkan hasil pengujian menunjukkan bahwa secara signifikan variabel Kemiskinan memengaruhi variabel Ketimpangan Distribusi Pendapatan dapat dilihat dari nilai prob. lebih kecil dari 0.05 yaitu 0.0152. Namun disisi lain, variabel Ketimpangan Distribusi Pendapatan secara signifikan tidak memengaruhi variabel Kemiskinan dengan dibuktikan oleh nilai prob lebih besar dari 0.05 yaitu sebesar 0.6274. Maka dapat disimpulkan bahwa terdapat hubungan kausalitas satu arah antara variabel kemiskinan dengan ketimpangan distribusi pendapatan di Kabupaten Badung.

Variabel Pertumbuhan Ekonomi secara signifikan tidak memengaruhi variabel Kemiskinan dengan dibuktikan oleh nilai prob. lebih besar dari 0.05 yaitu sebesar 0.1374 . Namun disisi lain, variabel Kemiskinan memengaruhi variabel Pertumbuhan Ekonomi yang dapat dilihat dari nilai prob lebih kecil dari 0.05 yaitu 0.2845 . Maka dapat disimpulkan bahwa terdapat hubungan kausalitas satu arah antara variabel kemiskinan dengan pertumbuhan ekonomi di Kabupaten Badung.

Variabel Sektor Pariwisata secara signifikan memengaruhi variabel Kemiskinan dengan dibuktikan oleh nilai prob. lebih besar dari 0.05 yaitu sebesar 0.0340. Variabel Kemiskinan secara signifikan tidak memengaruhi variabel Sektor Pariwisata yang dilihat dari nilai prob lebih besar dari 
0.05 yaitu 0.7210 . Maka dapat disimpulkan bahwa tidak terdapat hubungan kausalitas antara variabel kemiskinan dengan pertumbuhan ekonomi di Kabupaten Badung.

Hasil uji normalitas menunjukkan nilai jarque-bera pada model regresi adalah 0.064469 dan nilai probability sebesar 0.968279 lebih besar dari $\alpha=0,05$ yang menyatakan bahwa data sudah berdistribusi normal atau lulus uji normalitas. Hasil uji heteroskedastisitas yang dilakukan menunjukkan bahwa nilai probability pada variabel independen Ketimpangan Distribusi Pendapatan sebesar 0.1988, variabel Pertumbuhan Ekonomi sebesar 0.8916 dan variabel Sektor Pariwisata sebesar 0.5508 yang memiliki arti bahwa nilai signifikansi $>0,05$ sehingga dapat disimpulkan bahwa model regresi tidak mengalami masalah heteroskedastisitas. Hasil uji autokorelasi menggunakan BreuschGodfrey Serial Correlation LM Test diperoleh nilai Prob. F (2,19) sebesar 0.2004 dan nilai Prob. ChiSquare (2) sebesar 0.1429 lebih besar dari 0,05. Hal ini menandakan bahwa model regresi tidak terdapat gejala autokorelasi. Hasil uji multikolinearitas diperoleh nilai centered VIF dari variable Ketimpangan Distribusi Pendapatan sebesar 1.094178, nilai dari variabel Pertumbuhan Ekonomi sebesar 1.333706 dan nilai dari variabel Pertumbuhan Ekonomi sebesar 1.272683 maka dapat disimpulkan bahwa masing-masing variabel independen memiliki nilai centered VIF kurang dari 10 maka model regresi dapat dikatakan tidak mengandung gejala multikolinearitas. Oleh karena semua variable telah lolos uji asumsi klasik, maka model regresi sudah dikatakan layak untuk digunakan analisis lebih lanjut.

Tabel 8.

Hasil Uji Regresi Linear Berganda

\begin{tabular}{lrllc}
\hline \multicolumn{1}{c}{ Variable } & Coefficient & Std. Error & t-Statistic & Prob. \\
\hline C & -16.23631 & 4.464546 & -3.636721 & 0.0015 \\
KDP & -7.186885 & 6.584447 & -1.091494 & 0.2874 \\
PE & 0.130294 & 0.134182 & 0.971028 & 0.3426 \\
SP & 0.896253 & 0.091391 & 9.806811 & 0.0000 \\
\hline R-squared & 0.848622 & Mean dependent var & 17.6588 \\
Adjusted R-squared & 0.826997 & S.D. dependent var & 3.932927 \\
S.E. of regression & 1.635848 & Akaike info criterion & 3.967847 \\
Sum squared resid & 56.19599 & Schwarz criterion & 4.162867 \\
Log likelihood & -45.59808 & Hannan-Quinn criter. & 4.021937 \\
F-statistic & 39.2419 & Durbin-Watson stat & 1.258371 \\
Prob(F-statistic) & 0.0000 & & \\
\hline Sumber: Data diolah dengan eviews 9, 2021 & &
\end{tabular}

Sumber: Data diolah dengan eviews 9, 2021

Analisis Kausalitas Antara Pertumbuhan Ekonomi, Sektor Pariwisata, Ketimpangan Distribusi Pendapatan dan Kemiskinan di Kabupaten Badung, I Komang Wiradnyana dan I.K.G.Bendesa 
Berdasarkan hasil output Eviews 9, diperoleh persamaan regresi sebagai berikut:

$$
\mathrm{Y}=-16.23631-7.186885 \mathrm{KDP}+0.130294 \mathrm{PE}+0.896253 \mathrm{SP}
$$

Keterangan:

$\begin{array}{rlrl}\mathrm{Y} & = & \text { variabel terikat yaitu jumlah penduduk miskin } \\ \mathrm{a} & = & \text { konstanta } \\ \beta_{1,} \beta_{2,}, \beta_{3}, \beta_{\mathrm{i}} & = & \text { keefisien regresi variabel } \mathrm{X}_{\mathrm{I}}, \mathrm{X}_{2}, \mathrm{X}_{3,} \text {, dan } \mathrm{X}_{\mathrm{i}} \\ \mathrm{X}_{1}, \mathrm{X}_{2,} \mathrm{X}_{3} & = & \text { variabel independen yaitu Pertumbuhan Ekonomi (PE), Ketimpangan Distribusi } \\ & & \text { Pendapatan (KDP), dan Sektor Pariwisata (SP) } \\ \mathrm{e} & \text { error term (tingkat kesalahan) }\end{array}$

Hasil analisis uji statistik yaitu Uji $F$ diperoleh $F_{\text {hitung }}(39.24190)>F_{\text {tabel }}(3,07)$ dengan probabilitas sebesar $0.000000<0,05$, artinya variabel pertumbuhan ekonomi, sektor pariwisata dan ketimpangan distribusi pendapatan secara simultan berpengaruh positif dan signifikan terhadap kemiskinan di Kabupaten Badung. Koefisien determinasi ( $\mathrm{R}$ square) menunjukan bahwa variabel pertumbuhan ekonomi, ketimpangan distribusi pendapatan dan sektor pariwisata berpengaruh terhadap kemiskinan sebesar 85 persen. Sedangkan sebesar 15 persen kemiskinan dipengaruhi oleh variabel lain yang tidak dimasukan dalam model regresi. Walaupun dipengaruhi oleh pertumbuhan ekonomi dan ketimpangan distribusi pendapatan, namun sektor pariwisata memberikan peluang ekonomi untuk masyarakat sekitar serta secara tidak langsung akan meningkat pertumbuhan ekonomi. Dengan adanya peluang pekerjaan akan meningkatkan pendapatan sehingga mampu terbebas dari kemiskinan.

Berdasarkan hasil pengujian diperoleh nilai $\mathrm{t}_{\text {hitung }}$ sebesar -1.091494 lebih kecil dari $\mathrm{t}_{\text {tabel }}$ 1.72074 dan nilai prob. yang diperoleh sebesar $0.2874>0.05$, maka secara parsial ketimpangan distribusi pendapatan tidak berpengaruh signifikan terhadap jumlah penduduk miskin di Kabupaten Badung. Hasil analisis kausalitas menunjukkan bahwa tidak terdapat hubungan kausalitas antara ketimpangan distribusi pendapatan dengan kemiskinan dilihat dari nilai probability lebih besar dari 0.05. Maka dapat diartikan bahwa ketimpangan distribusi pendapatan tidak menyebabkan penurunan angka kemiskinan di Kabupaten Badung. Hasil ini sejalan dengan penelitian yang dilakukan oleh Anton (2016) yang menyatakan bahwa ketimpangan distribusi pendapatan tidak berpengaruh secara signifikan terhadap kemiskinan di Sulawesi Utara.

Hal ini dikarenakan tingkat rata-rata seluruh masyarakat di suatu daerah tersebut berada pada garis kemiskinan maka hal ini tidak akan memengaruhi tingkat ketimpangan. Ketimpangan distribusi pendapatan tidak berpengaruh signifikan terhadap kemiskinan di Kabupaten Badung disebabkan karena masyarakat Kabupaten Badung khususnya di bagian utara belum sepenuhnya dapat terserap oleh pesatnya perkembangan pariwisata. Hal tersebut dibuktikan dengan masih dominannya sektor pertanian di daerah tersebut. Daerah yang yang mampu menyerap sektor pariwisata akan semakin maju dan meninggalkan daerah (bagian utara) yang masih bergantung pada sektor pertanian.

Berdasarkan hasil pengujian diperoleh nilai $t_{\text {hitung }}$ sebesar 0.971028 lebih kecil dari $t_{\text {tabel }}$ 1.72074 dan nilai prob. yang diperoleh sebesar $0.3426>0.05$, maka secara parsial pertumbuhan ekonomi tidak berpengaruh signifikan terhadap jumlah penduduk miskin di Kabupaten Badung. Hasil analisis kausalitas menunjukkan bahwa tidak terdapat hubungan kausalitas antara pertumbuhan ekonomi dan kemiskinan yang dilihat dari nilai probability lebih besar dari 0.05. Maka dapat diartikan bahwa peningkatan kapasitas ekonomi tidak berpengaruh terhadap penurunan penduduk miskin di Kabupaten Badung.

Analisis Kausalitas Antara Pertumbuhan Ekonomi, Sektor Pariwisata, Ketimpangan Distribusi Pendapatan dan Kemiskinan di Kabupaten Badung, I Komang Wiradnyana dan I.K.G.Bendesa 
Pertumbuhan ekonomi di Kabupaten Badung tidak berpengaruh signifikan terhadap jumlah penduduk miskin disebabkan oleh banyaknya pekerja yang berasal dari luar daerah yang menjadi tenaga kerja sehingga pertumbuhan ekonomi akan dibawa ke daerah asal pekerja. Selain itu persaingan dunia kerja yang semakin ketat menyebabkan penduduk lokal kalah bersaing dengan penduduk luar daerah. Peran pemerintah juga diperlukan dalam mendistribukan kue pertumbuhan ekonomi agar terjadinya pemerataan di setiap wilayah. Selaras dengan penelitian yang dilakukan oleh Ainul (2018) menemukan bahwa tidak terdapat hubungan kausalitas antara kemiskinan dengan pertumbuhan ekonomi.

Berdasarkan hasil pengujian diperoleh nilai $t_{\text {hitung }}$ sebesar 9.806811 lebih besar dari $t_{\text {tabel }}$ 1.72074 dan hasil signifikansi yang diperoleh sebesar $0.0000<0.05$, maka secara parsial sektor pariwisata berpengaruh positif dan signifikan terhadap jumlah penduduk miskin di Kabupaten Badung. Hal ini ditunjukkan dengan nilai koefisien variabel sektor pariwisata sebesar 0.896253 dengan tanda positif. Hal ini berarti bahwa, apabila variabel independen sektor pariwisata mengalami kenaikan sebesar 1 persen sementara variabel independen pertumbuhan ekonomi dan ketimpangan distribusi pendapatan bersifat tetap maka jumlah penduduk miskin akan mengalami penurunan sebesar 0.896253 persen.

Hasil analisis kausalitas memperkuat bahwa terdapat hubungan kausalitas antara sektor pariwisata dengan kemiskinan yang dilihat dari nilai probability lebih kecil dari 0.05. Maka dapat diartikan bahwa sektor pariwisata memengaruhi kemiskinan atau peningkatan sumbangan sektor pariwisata terhadap PDRB menyebabkan penurunan angka kemiskinan di Kabupaten Badung. Hasil penelitian ini sejalan dengan penelitian yang dilakukan oleh Daniel (2011) yang menunjukkan bahwa sektor industri pariwisata di Provinsi Nusa Tenggara Timur memberikan kontribusi yang berarti dalam menurunkan tingkat kemiskinan.

Penelitian yang dilakukan Mbaiwa (2019) menemukan bahwa sektor pariwisata berkontribusi secara signifikan terhadap pembangunan ekonomi pedesaan dan pengentasan kemiskinan yang terjadi di sebagian besar wilayah Okvango. Pesatnya perkembangan pariwisata akan dapat memutus rantai setan kemiskinan sesuai teori Nurkse yang menyatakan bahwa kemiskinan terjadi karena kekurangan modal menyebabkan rendahnya produktivitas sehingga pendapatan menjadi rendah dan diikuti dengan rendahnya investasi, pada akhiirnya akan terjadi keurangan modal.

\section{SIMPULAN DAN SARAN}

Berdasarkan hasil analisis dan pembahasan yang telah diuraikan sebelumnya, maka dapat ditarik kesimpulan bahwa terdapat hubungan jangka panjang antara variabel pertumbuhan ekonomi, sektor pariwisata terhadap ketimpangan distribusi pendapatan dan kemiskinan di Kabupaten Badung. Tidak terdapat hubungan antara ketimpangan distribusi pendapatan dan pertumbuhan ekonomi dengan kemiskinan di Kabupaten Badung. Terdapat hubungan kausalitas antara sektor pariwisata dengan kemiskinan di Kabupaten Badung. Secara simultan pertumbuhan ekonomi, ketimpangan distribusi pendapatan dan sektor pariwisata berpengaruh signifikan terhadap kemiskinan di Kabupaten Badung, dan secara parsial hanya sektor pariwisata yang berpengaruh negative dan signifikan terhadap kemiskinan di Kabupaten Badung.

Berdasarkan hasil penelitian dan simpulan diatas, maka dapat diajukan saran bagi pemerintah diharapkan mengembangkan dan membangunan sektor pariwisata secara merata agar mampu meningkatkan lapangan pekerjaan dan meningkatkan pendapatan bagi masyarakat Kabupaten

Analisis Kausalitas Antara Pertumbuhan Ekonomi, Sektor Pariwisata, Ketimpangan Distribusi Pendapatan dan Kemiskinan di Kabupaten Badung, I Komang Wiradnyana dan I.K.G.Bendesa 
Badung. Masyarakat diharapkan mendukung kebijakan pengembangan pariwisata dengan memperkuat adat dan tradisi di masing-masing desa agar mampu menarik minat wisatawan datang ke Badung. Peneliti selanjutnya agar dapat mengembangkan hasil penelitian ini dengan mempertimbangkan variabel - variabel lain seperti lapangan pekerjaan, pendidikan dan investasi sehingga mampu memberikan hasil analisis yang lebih baik.

\section{REFERENSI}

Ainul F., Agus S. (2018). Kausalitas Korupsi, Kemiskinan, dan Pertumbuhan Ekonomi pada 8 Kota di Indonesia. Fakultas Ekonomi dan Bisnis Universitas Brawijaya. 7(2). 1-10.

Anton Tri, W. (2016). Analisis Keterkaitan Pertumbuhan Ekonomi, Ketimpangan Pendapatan dan Pengentasan Kemiskinan di Provinsi Sulawesi Utara Tahun 2000 - 2010. Jurnal Berkala Ilmiah Efisiensi. 16(02).418-428.

Badan Pusat Statistik. (2020). Gini Rasio Provinsi Bali Menurut Kabupaten/Kota, 2009-2018. Januari. BPS Bali. Denpasar.

Badan Pusat Statistik. (2020). Laju Pertumbuhan Ekonomi/PDRB Kabupaten/Kota Tahun 2011-2019. Januari. BPS Bali. Denpasar

Badan Pusat Statistik. (2020). Persentase Penduduk dan Jumlah Penduduk Miskin di Provinsi Bali Tahun 20102019. Januari. BPS Bali. Denpasar

Bagus, Adhitya, Lilis Siti Bariah \& Suprapto. (2020). Pengaruh Pariwisata terhadap Ketimpangan Pendapatan: Studi Kasus Provinsi Daerah Istimewa Yogyakarta. Jurnal Ilmiah Universitas Batanghari Jambi, 20(2).456-462.

Daniel, Mutis. (2010). Implikasi Industri Pariwisata Terhadap Pertumbuhan Ekonomi, Kesempatan Kerja, Pendapatan Perkapita, dan Asli Daerah serta Tingkat Kemiskinan, di Nusa Tenggara Timur. Jurnal Ilmu Ekonomi Universitas Borobudur. 6(1). 25-49.

Dariwardani, Inna. (2014). Analisis Dinamika Kemiskinan (Poverty Dynamics) di Bali Berdasarkan Data Susenas Panel 2008 - 2010. Jurnal Ekonomi Kuantitatif Terapan. 7(1).1-82.

Dinny, M. (2020). Kunjungan Wisman ke Indonesia Menurun pada Oktober 2019. Liputan6 website

Hadi, Sasana \& Panji Kusuma. (2018). Government Expenditure inequality and Poverty in Indonesia. International Conference on Economics, Business and Economic Education, 3(10).142-153.

Ismalisa, Ali Anis. (2019). Analisis Kausalitas Sektor Pariwisata, Indeks Pembangunan Manusia dan Pertumbuhan Ekonomi di Sumatera Barat. Jurnal Kajian Ekonomi dan Pembangunan, 1(2).1-10.

Mbaiwa, Joseph. (2005). Enclave Tourism and Its Socio-Economic Impacts in the Okavango Delta. University of BotswanTourism Management, 26(2). 157-172

Nova, Dewi O., Candra Fajri Ananda, Sasongko. (2019). An Analysis of Development Inequality and Economic Growth against Poverty in Papua Province in 2010-2018. Advances in Economics, Business and Management Research, 144(1). https://doi.org/10.2991/aebmr.k.200606.053

Pradeep, Agrawal. (2008). Economic Growth and Poverty Reduction: Evidence from Kazakhstan. Asian Development Review. 24(2).90-115.

Rifki, Ihsan, Hasdi Aimon, Alpon Satrianto. 2018. Analisis Kausalitas Inflasi, Ketimpangan Pendapatan, dan Pertumbuhan Ekonomi di Indonesia. Ecogen. 1(3).701-711.

Risqi, Noor, Hidayati Putri, Susilo, Putu Mahardika Adi Saputra. 2019. Decentralization and Financial Local Governments Performance: How Does Fiscal Autonomy Affect Spending, Economic Growth, and Poverty in East Java Indonesia?. Journal of Poverty, Investment and Development, 51(1),37-49.

Samimi, A. J., Sadeghi, S., \& Sadeghi, S. (2011). Tourism and Economic Growth in Developing Countries: PVAR Approach. Middle-East. Journal of Scientific Research, 10(1).28-32.

Sirilius, Seran. (2017). Hubungan antara Pendidikan, Penganguran dan Pertumbuhan Ekonomi Dengan Kemiskinan. Jurnal Ekonomi Kuantitatif Terapan. 10 (2).59-71.

Sovia, Dewi, M. Shabri Abd. Majid, Aliasuddin, Salina Kassim. (2018). Dynamics of Financial Development, Economic Growth, and Poverty Alleviation: The Indonesian Experience. South East European Journal of Economics and Business. 13(1).17-30.

Suhel, Abdul Bashir. (2018). The Role of Tourism Toward Economic Growth in the Local Economy. Economic Journal of Emerging Markets, 10(1). 32-39.

Analisis Kausalitas Antara Pertumbuhan Ekonomi, Sektor Pariwisata, Ketimpangan Distribusi Pendapatan dan Kemiskinan di Kabupaten Badung, I Komang Wiradnyana dan I.K.G.Bendesa 
Todaro, Michael p., Stephen c. smith. (2011). Pembangunan ekonomi (edisi sebelas jilid 1), Jakarta: Erlangga Ulke, (2011). Econometric Analysis of Import and Inflation Relationship in Turkey between 1995 and 2010. Journal of Economic and Social Studies.1(1), 69-86.

Windia, Wayan. (2015). Sekali Lagi Tentang Pengentasan Kemiskinan (di Bali). Piramida. 11(1).1-7. 